\title{
Mixing of water in a carbonate aquifer, southern Italy, analysed through stable isotope investigations
}

\author{
Emma Petrella*1 and Fulvio Celico ${ }^{1,2}$ \\ ${ }^{1}$ Department of Biosciences and Environment, University of Molise, Contrada Fonte Lappone, 86090, Pesche (IS), Italy \\ ${ }^{2}$ Department of Physics and Earth Sciences "Macedonio Melloni”, University of Parma, Parco Area delle Scienze 157A, 43100, Parma, Italy
}

\begin{abstract}
Mixing of water was analysed in a carbonate aquifer, southern Italy, through stable isotope investigations $\left({ }^{18} \mathrm{O}, \delta^{2} \mathrm{H}\right)$. The input signal (rainwater) was compared with the isotopic content of a 35-meter groundwater vertical profile, over a 1-year period. Within the studied aquifer, recharge and flow are diffuse in a well-connected fissure network.

At the test site, the comparison between input and groundwater isotopic signals illustrates that no efficient mixing takes place in the whole unsaturated zone, between the fresh infiltration water and the stored water.

When analysing the stable isotope composition of groundwater, significant variations were observed above the threshold elevation of $1062 \mathrm{~m}$ asl, while a nearly constant composition was observed below the same threshold. Thus, temporal variations in stable isotope composition of rainwater are completely attenuated just in the deeper phreatic zone.

On the whole, taking into consideration also the results of previous studies in the same area, the investigations showed that physical characteristics of the carbonate bedrock, as well as aquifer heterogeneity, are factors of utmost importance in influencing the complete mixing of water. These findings suggest a more complex scenario at catchment scale.
\end{abstract}

Keywords: $\quad$ aquifer heterogeneity; carbonate aquifer; mixing processes; stable isotopes; southern Italy Received 21 November 2011; Revised 16 September 2012; Accepted 12 October 2012

Citation: Petrella E. and Celico F. 2013. Mixing of water in a carbonate aquifer, southern Italy, analysed through stable isotope investigations. International Journal of Speleology, 42 (1), 25-33. Tampa, FL (USA) ISSN 0392-6672 http://dx.doi.org/10.5038/1827-806X.42.1.4

\section{INTRODUCTION}

At catchment scale, hydrology in carbonate systems can be characterised by (a) diffuse or concentrated recharge and (b) diffuse or concentrated flow (Atkinson, 1977; Williams, 1983; White, 1988; Ford $\&$ Williams, 1989). In the present study the attention is focused on a carbonate aquifer system where recharge and flow are diffuse in a well-connected fissure network (Celico et al., 2006; Petrella et al., 2008), but little information is available concerning mixing of water within the same system. Thus, the main purpose of this research was the identification of the compartments of the aquifer system where these processes take place.

Several studies have been carried out in carbonate aquifers using stable isotopes $\left(\delta^{18} \mathrm{O}\right.$ and $\left.\delta^{2} \mathrm{H}\right)$ as conservative tracers (e.g. Maloszewski et al., 2002) to investigate the role of the unsaturated zone only or of both the saturated and the unsaturated ones in mixing processes. However, different findings were obtained in different test sites. Yonge et al. (1985) found in three cave sites in the eastern U.S.A. (Tumbling Creek Cave, Missouri; Shenandoah Caverns, Virginia; Indian Echo Caverns, Pennsylvania) a nearly complete mixing of water in the first $10 \div 15$ meters of the vadose zone, even if the structural and lithological settings of the three cave systems were felt to be sufficiently different. Schwarz et al. (2009), in the Blautopf Catchment, one of the largest karst areas in Germany, found that the isotope signals in seepage water in the caves (analysed at a depth ranging from 8 to 45 meters from the surface) were almost completely buffered and ranged around an average $\delta^{18} \mathrm{O}$ value. Conversely, Cruz Jr. et al. (2005), in the Santana cave systems in subtropical Brazil, found that the isotopic signal of water collected at drip sites, from 100 to 300 meters below ground, are directly related in a nonlinear fashion with rainwater input into the karst.

Within the present study, mixing processes were analysed at site scale through isotopic investigations $\left(\delta^{18} \mathrm{O}, \delta^{2} \mathrm{H}\right)$ over a 1 -year period, by comparing the input signal (rainwater) with the isotopic content of a 35-meter groundwater vertical profile. Due to the 
absence of accessible caves and conduits, cave dripwater studies were not possible. Thus, the types of vadose flow (preferential or fracture fed; matrix or seepage fed; Baker \& Brundson, 2003) were not directly investigated, contrary to other studies (eg. Baker et al., 1997; Genty \& Deflandre, 1998; Baker et al., 2000; Kaufman et al., 2003; Tooth \& Fairchild, 2003; Spötl et al., 2005; Karmann et al., 2007; McDonald \& Drysdale, 2007; Lange et al., 2010). The role of the unsaturated zone (thickness ranging from 27 to 62 meters during the observation period) was analysed based on observations made within the groundwater profile in a purpose-drilled well.

\section{DESCRIPTION OF THE FIELD SITE}

The focus of the work lies on a carbonate aquifer (Acqua dei Faggi, Longano, southern Italy; Fig. 1) formed predominantly of limestone (Monte Calvello and Monaci Formations; Cretaceous-Oligocene) and subordinately of lower permeability rocks (Macchiagodena Formation; Oligocene-Burdigalian) (De Corso et al., 1998). The Macchiagodena Formation consists mainly of marls and marly limestone. Monte Calvello and Monaci Formations are mainly made up of calcarenites and calcirudites with intergranular material composed predominantly of spatic cement, biocalcarenites and biocalcirudites. Carbonates have very low primary porosity, but are extensively fissured. Natural gradient tracer tests yielded an opening porosity given by fissures of $2.3 \times 10^{-4}$ (Petrella et al., 2008). Lugeon tests showed hydraulic conductivity of limestone in the order of $10^{-6} \mathrm{~m} \mathrm{~s}^{-1}$ (Petrella et al., 2007). Carbonate rocks are exposed or lie below a cover of pyroclastic origin (Naclerio et al., 2008).

The aquifer is bounded by fault zones that act as barriers to groundwater flow and compartmentalise the aquifer system (Celico et al., 2006; Petrella et al., 2009a). However, some fault zones, where calcite-filled cataclasite is observed, allow significant groundwater flowthrough, and the interdependence of hydraulic heads up- and down-gradient of these faults has been observed (Celico et al., 2006). The aquifer behaves as a basin-in-series system, where the hydraulic head shows a step-like shape and seasonal and temporary springs occur along some fault zones (Petrella et al., 2009a). At the basin scale, the groundwater flows westwards towards the perennial spring (Fig. 1).

The carbonate medium is laterally and vertically well connected in the subsurface, and the fracture spacing is sufficiently dense to apply the continuum approach to describe groundwater flow at the metric scale (Petrella et al., 2007). A significant vertical heterogeneity of the carbonate bedrock has been found, due to differences in fissuring and karstification with depth (Petrella et al., 2007). Darcy's law can be applied in epikarstic horizons with some karstification, and groundwater flow is also expected to be laminar in diffusely karstified epikarst and in the underlying fissured bedrock (Petrella et al., 2008).

The groundwater responds rapidly to recharge events, due to fast and diffuse rainwater infiltration. The funnelling effect into larger shafts does not play an important role in the hydrogeological behaviour of the aquifer (Petrella et al., 2007). At the aquifer scale, the thickness of the unsaturated medium ranges from a few centimetres (Celico et al., 2006) to some hundreds of meters (Petrella et al., 2009a), depending on the area and the groundwater level fluctuations.

\section{MATERIALS AND METHODS}

\section{Hydrogeological investigations}

The hydraulic head was measured on an hourly basis with a pressure transducer, from May 2008 to August 2009, at well P1 (Fig. 1). The well P1 was drilled in order to analyse mixing processes in one of the sites where the unsaturated zone is relatively

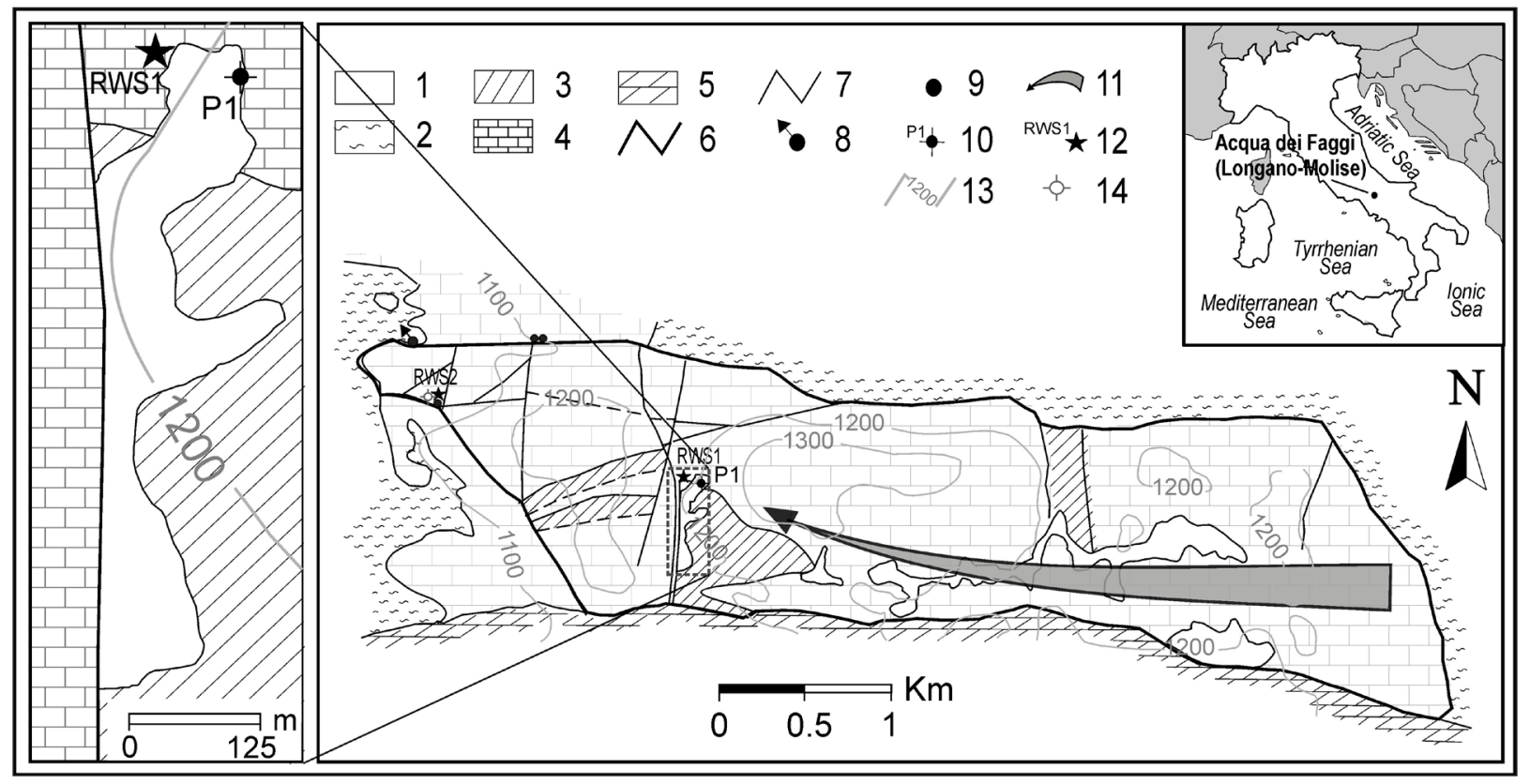

Fig. 1. Hydrogeological map (1 Quaternary deposits; 2 marls and clays; 3 marls and marly limestone; 4 limestone; 5 dolostone; 6 aquifer boundary; 7 fault; 8 perennial spring; 9 seasonal spring; 10 well; 11 main groundwater flow direction; 12 Rain Water Sampler [RWS]; 13 elevation contour line; the numbers are expressed in $\mathrm{m}$ asl; 14 location of the well shown in Fig. 8). 
thin, if compared with the rest of the studied aquifer system. The well (130 m deep) is drilled through a few meters of cover of pyroclastic origin and then through limestone. It is full-screened, except for the first 5 meters that are sealed in order to prevent the local infiltration of surface water. This well is the same borehole that was used in a previous study (Petrella et al., 2009b), during which experimental data demonstrated the local diffuse infiltration of rainwater through topsoil and limestone bedrock, and showed the effect of this infiltration on the shallower groundwater in terms of salinity modification. Other investigations, in Petrella et al. (2009b), were carried out only to determine the origin of the lower- and the highersalinity groundwater which were detected during this survey.

This well is therefore useful to analyse other processes, such as mixing, related to the interaction between fresh infiltration water and groundwater.

\section{Water sampling}

\section{Rainwater}

Rainwater samples for isotopic $\left(\delta^{18} \mathrm{O}, \delta^{2} \mathrm{H}\right)$ analyses were collected at a rain sampler (RWS1), located within the aquifer system, close to P1, at 1150 meters above sea level ( $\mathrm{m}$ asl; Fig. 1). The sampling was carried out on a monthly basis from May 2008 to August 2009, to compare the input isotopic signal with the isotopic content of groundwater, during the same observation period.

A more detailed analysis of rainwater isotopic content was obtained collecting samples on a weekly basis, from April 2006 to January 2008, at another rain sampler (RWS2) located within the same aquifer system (1014 m asl). Polyethylene bottles $(10 \mathrm{~L})$ containing about $300 \mathrm{ml}$ of vaseline oil to prevent evaporation processes even under very hot summer conditions were used to collect the samples. Oil contamination was carefully avoided while syringing the water samples out of the bottle.

\section{Groundwater}

Groundwater samples for stable isotope $\left(\delta^{18} \mathrm{O}\right.$, $\left.\delta^{2} \mathrm{H}\right)$ analyses were collected at P1 at different depths, using a 5-m-depth interval. Preliminary investigations suggested that a maximum investigated depth of $35 \mathrm{~m}$ below the groundwater table was necessary to thoroughly analyse variations of the groundwater isotopic signal at the study site. Collection was carried out 10 times, from June 2008 to August 2009.

A stainless steel bailer was used $\left(250 \mathrm{~cm}^{3}\right.$ volume) fitted with a one-way valve at the lower end and attached to $6 \mathrm{~mm}$ plastic tubing at the upper end. The upper end of the tubing was attached at the surface to a pump. The bailer was pressurised with air before lowering it to the chosen sampling depth. Once at the chosen depth, the pressure was released, allowing water to enter the bailer. After the bailer was withdrawn, a sample of water was transferred to a polyethylene bottle.

\section{Isotopic analyses}

Isotopic analyses $\left(\delta^{18} \mathrm{O}, \delta^{2} \mathrm{H}\right)$ were carried out at the Laboratorio di Geochimica Isotopica of the University of Parma (Italy), and at the Istituto di Geoscienze e Georisorse of the CNR, Pisa (Italy), using Isotope Ratio Mass Spectrometry (IRMS). The analytical precision was $\pm 0.1 \%$ o for $\delta^{18} \mathrm{O}, \pm 1.0 \%$ o for $\delta^{2} \mathrm{H}$.

The compositions of $\delta^{18} \mathrm{O}$ and $\delta^{2} \mathrm{H}$ are reported in $\delta \%$ vs. V-SMOW (Vienna Standard Mean Ocean Water) standard.

\section{Mixing analysis}

The two-component isotopic separation technique (Pinder \& Jones, 1969; Sklash \& Farvolden, 1979) was used to calculate the proportion of freshwater mixed with pre-event groundwater along the investigated groundwater profile, during the main recharge events. The mixing was calculated using eq. (1):

$$
\mathrm{X}_{\mathrm{T}} \mathrm{C}_{\mathrm{T}}=\mathrm{X}_{\mathrm{A}} \mathrm{C}_{\mathrm{A}}+\mathrm{X}_{\mathrm{B}} \mathrm{C}_{\mathrm{B}}
$$

where $X_{T}$ is groundwater at any depth, $X_{A}$ is preevent groundwater (corresponding to the deepest sampled one along the investigated profile), $X_{B}$ is the event water (corresponding to rainwater collected at RWS1), $C_{T}, C_{A}$, and $C_{B}$ are $\delta^{18} \mathrm{O}$ composition (\%o) of groundwater at any depth, of pre-event groundwater, and of event water, respectively.

\section{RESULTS}

\section{Input isotopic signal}

With regard to stable isotopes composition of rainfall (Tab. 1) it is possible to calculate the following equation that describes the Local Meteoric Water Line (LMWL):

$$
\delta^{2} \mathrm{H}=7.7 \delta^{18} \mathrm{O}+12.7\left(\mathrm{R}^{2}=0.96 ; \mathrm{n} \text { of samples }=15\right)
$$

This equation is very close (Fig. 2) to the Western Mediterranean Meteoric Water Line (WMMWL; $\delta^{2} \mathrm{H}$ $\left.=8 \delta^{18} \mathrm{O}+13.7\right)$ found by Celle-Jeanton et al. (2001) in several stations located in the Mediterranean seaside countries. All rainwater samples fall between the Global Meteoric Water Line (GMWL; $\delta^{2} \mathrm{H}=8 \delta^{18} \mathrm{O}+10$; Craig, 1961) and the Easter Mediterranean Water Line (EMWL; $\delta^{2} \mathrm{H}=8 \delta^{18} \mathrm{O}$ + 22; Gat \& Carmi, 1970) underlining that the variability is influenced by both the Atlantic and the Mediterranean air masses. This is also evident from the deuterium excess values ( $d$ in Table 1 ). From May 2008 to August 2009 the weighted mean isotopic composition for the precipitation was $-7.88 \%$ o for $\delta^{18} \mathrm{O}$ and $-47.38 \%$ o for $\delta^{2} \mathrm{H}$. However, a significant temporal variability of the signal was observed in monthly cumulated rainfall, with values ranging from $-10.48 \%$ and $-5.11 \%$ for $\delta^{18} \mathrm{O}$ and from $-70.80 \%$ o to $-24.30 \%$ or $\delta^{2} \mathrm{H}$. The significant temporal variability of the input signal is more thoroughly observed in the samples collected weekly from April 2006 to January 2008 in RWS2, with values ranging from $-15.70 \%$ and $-2.61 \%$ for $\delta^{18} \mathrm{O}$ and from $-117.46 \%$ o to $-9.58 \%$ o for $\delta^{2} \mathrm{H}$. 
Table 1. Isotopic and $d$-excess values in RWS1 rainwater samples.

\begin{tabular}{|c|c|c|c|}
\hline & $\begin{array}{l}\delta^{18} \mathrm{O} \% \\
\text { (vs. V-SMOW) }\end{array}$ & $\begin{array}{l}\delta^{2} \mathrm{H} \% \\
\text { (vs. V-SMOW) }\end{array}$ & $d$-excess \\
\hline $04 / 06 / 2008$ & -8.01 & -51.40 & 12.68 \\
\hline $07 / 07 / 2008$ & -5.31 & -31.00 & 11.48 \\
\hline $31 / 07 / 2008$ & -5.78 & -31.70 & 14.54 \\
\hline 03/09/2008 & -5.84 & -31.90 & 14.82 \\
\hline $06 / 10 / 2008$ & -8.39 & -49.30 & 17.82 \\
\hline $03 / 11 / 2008$ & -5.11 & -24.30 & 16.58 \\
\hline $04 / 12 / 2008$ & -7.93 & -42.40 & 21.04 \\
\hline 09/01/2009 & -9.50 & -59.50 & 16.50 \\
\hline $03 / 02 / 2009$ & -10.48 & -70.80 & 13.04 \\
\hline $06 / 03 / 2009$ & -8.25 & -49.90 & 16.10 \\
\hline $09 / 04 / 2009$ & -5.38 & -27.90 & 15.14 \\
\hline $07 / 05 / 2009$ & -7.75 & -46.50 & 15.50 \\
\hline $10 / 06 / 2009$ & -5.77 & -34.30 & 11.86 \\
\hline $06 / 07 / 2009$ & -7.59 & -47.90 & 12.82 \\
\hline 06/08/2009 & - & - & - \\
\hline
\end{tabular}

\section{Groundwater isotopic signal}

After plotting the isotopic data of groundwater collected at different depths at $\mathrm{P} 1$ in the $\delta^{18} \mathrm{O}$ vs. $\delta^{2} \mathrm{H}$ scattergram (Fig. 2) it is observed that all samples are well situated along the LMWL, therefore suggesting a complete meteoric origin of groundwater within the whole investigated profile. However, interesting differences in groundwater isotopic content were observed with depth. Two main types of profiles (A and $B$ ) were detected within the 35-m-deep interval. Type A (full lines in Fig. 3) was observed during late recession, when the isotopic composition was homogeneous (variations were lower than the $2 \sigma$ error of the analyses) down to the maximum investigated depth. Type B (dashed lines in Fig. 3) was observed during recharge and early recession, when the

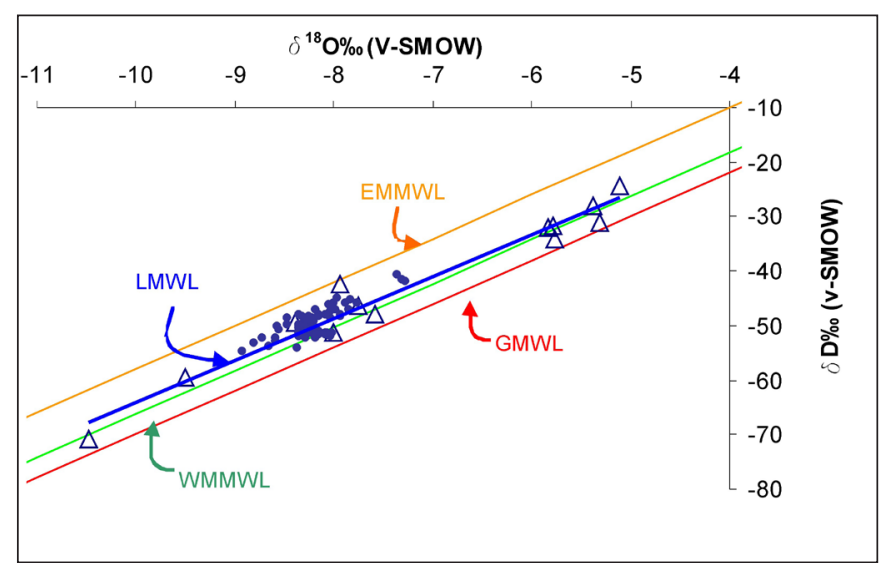

Fig. 2. $\delta^{18} \mathrm{O}$ vs. $\delta^{2} \mathrm{H}$ relationship in rainfall (triangles; Local Meteoric Water Line [LMWL]) and groundwater samples (full dots). The Global Meteoric Water Line (GMWL; Craig, 1961), the Eastern Mediterranean Meteoric Water Line (EMMWL; Gat \& Carmi, 1970) and the Western Mediterranean Meteoric Water Line (WMMWL; Celle-Jeanton et al., 2001) are given for reference.

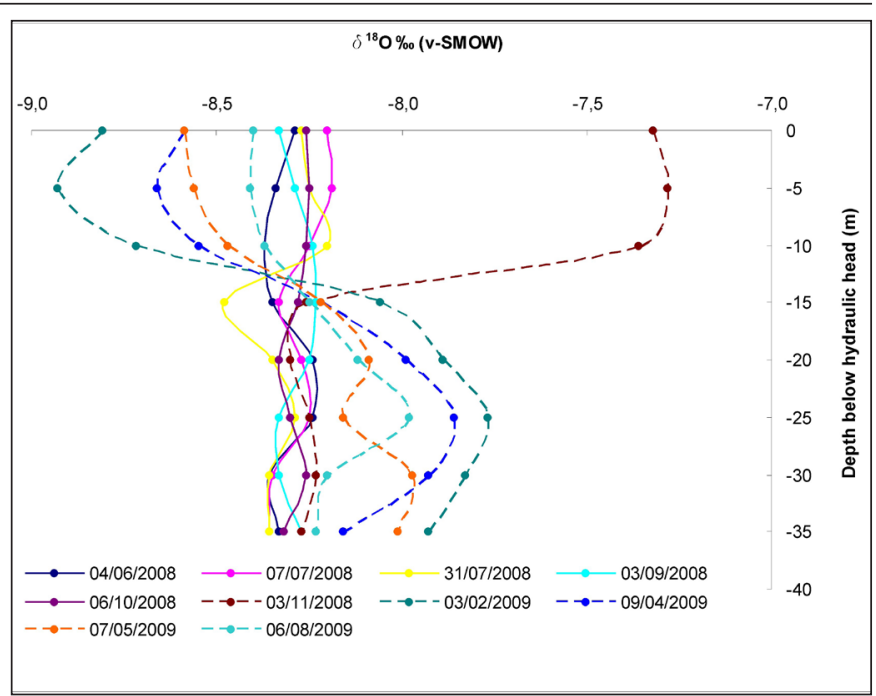

Fig. 3. Variations of $\delta^{18} \mathrm{O}$ below the hydraulic head. Full lines are referred to "type A" profiles, while dashed lines are referred to "type B" profiles.

isotopic composition varied significantly (variations were greater than the $2 \sigma$ error of the analyses) within the whole investigated profile.

\section{Comparison between rain- and groundwater signals}

The temporal variations of the input function were strongly, but not completely reduced at the groundwater table. Variations of groundwater isotopic content were observed at shallower depths below the hydraulic head, and were clearly due to mixing between groundwater and fresh infiltration water. In fact, taking into account only the recharge period (from November 2008 to May 2009) when the rainfall produces huge effective infiltration, the mixing analysis (Tab.2) shows that fresh infiltration water is up to $40 \%$ of the whole groundwater within the upper 10 meters below the hydraulic head in early November 2008 and in February 2009. Below this depth, the percentage of fresh infiltration water was negligible (less than $5 \%)$. The negative values of infiltrated water are in

Table 2. Percentage of fresh water in the whole groundwater, at different depths, during huge effective infiltration.

\begin{tabular}{|c|c|c|}
\hline $\begin{array}{l}\text { Depth below } \\
\text { groundwater level }(\mathrm{m})\end{array}$ & 03/11/2008 & $03 / 02 / 2009$ \\
\hline 0 & 30.1 & 34.6 \\
\hline-5 & 31.3 & 39.4 \\
\hline-10 & 28.8 & 31.1 \\
\hline-15 & 0.3 & 5.1 \\
\hline-20 & -0.9 & -1.6 \\
\hline-25 & 0.6 & -6.3 \\
\hline-30 & 1.3 & -3.9 \\
\hline-35 & 0.0 & 0.0 \\
\hline
\end{tabular}


the range of the error related to the two-component isotopic separation technique. This phenomenon has been thoroughly investigated and quantified during this recharge period, because the strong difference between the isotopic content of rainwater and that of pre-event groundwater, and the huge effective infiltration both allowed to distinguish in a detailed manner the influence of event water on pre-event groundwater (Fig. 4). This time span is enough to experimentally verify how mixing of water takes place within the unsaturated zone and the shallower saturated zone. In early April 2009, isotopically heavier rainwater caused a new slight increase in isotopic content of the same groundwater layer, but the difference in isotopic composition between end-members is not useful to thoroughly quantify the mixing, as carried out during the previous events. The isotopic content remained nearly constant in early May 2009, due to precipitation that was characterised by a composition very close to that of groundwater (Fig. 4). In such a scenario, the slight increase in isotopic content in the deeper groundwater, that was observed from February 2009 onwards, indicates a mixing between the upper and isotopically heavier, and the lower and isotopically lighter groundwater layer detected in November 2008 (Fig. 4). The absence of precipitation in June and July 2009 emphasised the results of this mixing in terms of isotopic composition of the different groundwater layers (Fig. 4).

The slight difference between the weighted mean isotopic composition of rainwater $\left(-7.88 \%\right.$ o for $\delta^{18} \mathrm{O}$ and $-47.38 \%$ for $\delta^{2} \mathrm{H}$ ) and the nearly-constant isotopic content of the deeper groundwater layer $\left(-8.22 \%\right.$ o \pm 0.15 for $\delta^{18} \mathrm{O}$, and $-49.30 \%$ o \pm 1.88 for $\left.\delta^{2} \mathrm{H}\right)$ is explained taking into consideration that the rainwater sampler (RWS1) is at an elevation lower than the mean altitude of the catchment area $\left(\delta^{18} \mathrm{O}\right.$ vertical gradient $-0.16 \%$ / $100 \mathrm{~m}$, Petrella et al., 2009a).

As a matter of fact, the comparison between input

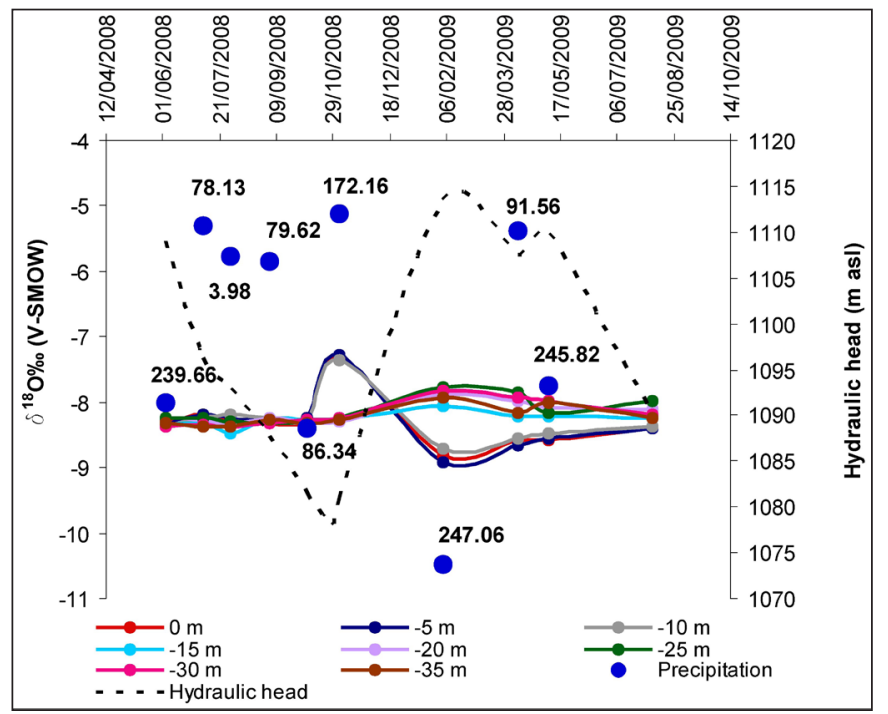

Fig. 4. Temporal variations of $\delta^{18} \mathrm{O}$ of groundwater at different depths below the hydraulic head (coloured lines with dots; the dots show the date of water collection), variations of monthly weighted mean $\delta^{18} \mathrm{O}$ of rainwater (blue dots; numbers are the amount of rainfall in $\mathrm{mm}$ ), and variation of the hydraulic head (dashed line). and groundwater isotopic signals illustrates that no complete mixing takes place in the whole unsaturated zone, between the fresh infiltration water and the stored water. This observation, together with the fast response of the hydraulic head to recharge events, suggests the widespread existence of an important vadose flow in larger fissures at the study site, even though the mobilisation of pre-event water from smaller fissures and rock matrix cannot be excluded. Existence and importance of diffuse and fast vadose flow in larger fissures is also in agreement with the short transit time observed when studying contaminant transport within the same system, induced by diffuse migration of microorganisms through the soil and the limestone bedrock (Celico et al., 2004a and b; Naclerio et al., 2008, 2009).

\section{DISCUSSION AND CONCLUSIONS}

When analysing the stable isotope composition of groundwater as a function of the depth below ground surface, significant variations (greater than the $2 \sigma$ error of the analyses) were observed above the threshold elevation of $1062 \mathrm{~m}$ asl ( 78 meters below the ground surface), while a nearly constant composition was observed below the same threshold (Fig. 5). These differences do not correspond to significant differences in terms of residence time, as demonstrated in a former study $\left({ }^{3} \mathrm{H}\right.$ content in both the upper and the lower groundwater layers is 4.5 Tritium Units; Petrella et al., 2009b).

These findings suggest that temporal variations in stable isotope composition of rainwater are not completely damped in the whole unsaturated medium, as well as in the upper phreatic zone, during recharge.

Since the dampening of the signal is well observed in the deeper phreatic zone, close to the depth at which geophysical investigations detected the transition between limestone with a well-connected fissure network $(\rho \cong 2500 \Omega \mathrm{m}$ ) and limestone with a poorly-developed fissure network $(\rho \cong 10000 \Omega$

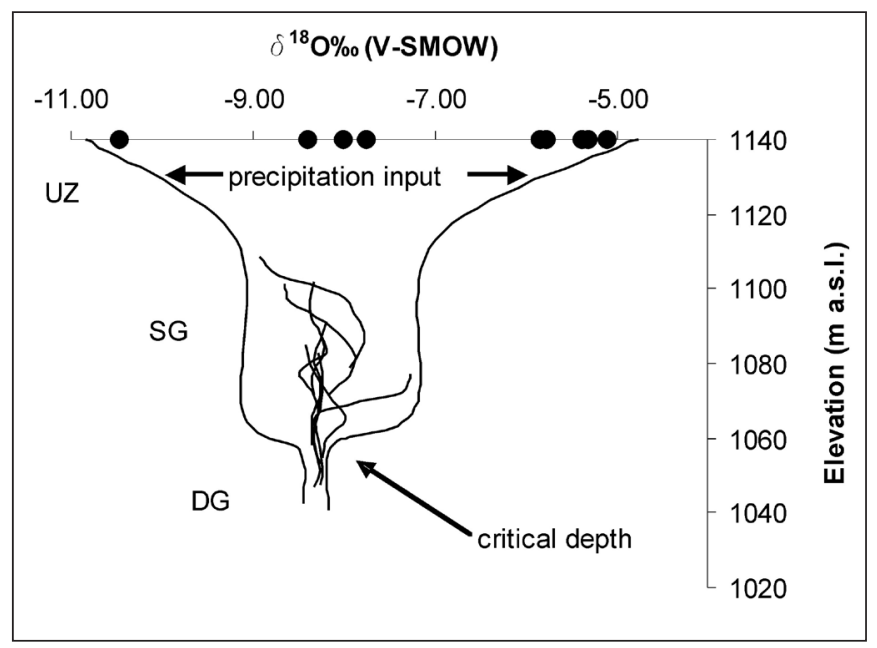

Fig. 5. Schematic of the attenuation of temporal isotope $\left(\delta^{18} \mathrm{O}\right)$ variations in recharge waters during infiltration through the unsaturated zone (UZ) and flow within the shallower (SG) and the deeper (DG) groundwater, and the critical depth below which isotopic variability is less than the analytical precision at the test site. The dots show the isotopic composition of precipitation at the test site during the study. 
m)(Petrella et al., 2009b), physical characteristics of the carbonate bedrock and aquifer heterogeneity are factors of utmost importance in influencing the complete mixing of water.

In a wider context, taking into consideration physical and hydraulic properties of the aquifer at catchment scale, as well as its heterogeneities, different scenarios are expected at the same scale, regarding mixing of water. The whole setting can be depicted as follows.

Coexistence of an upper several-meters-thick limestone bedrock with a well-developed fracture network (thicker than the epikarst only) and a lower limestone bedrock with a poorly-developed fracture network are principally due to stress release fracturing, which occurs because of unloading stress where rock has been removed. This phenomenon causes an increased density of joints and bedding plane partings in the near-surface bedrock (Ferguson, 1967; Sasowsky \& White, 1994). However, vertical heterogeneity can be further emphasised by mixing processes between groundwater and fresh infiltration water just below the water table of an unconfined aquifer. When saturated waters with different chemical composition mix, new aggressivity arises and widening of fissures can be caused, due to carbonate dissolution (e.g., Gabrovšek \& Dreybrodt, 2000; Romanov et al., 2003; Gabrovšek \& Dreybrodt, 2010). In the studied aquifer, great hydraulic head fluctuations were observed during each hydrologic year in several wells (30 to 100 meters; Petrella et al., 2007 and 2009a), therefore suggesting that this process can influence the widening of the fissures at really different depths and within relatively thick horizons, depending on the zone of the aquifer system, and the phase of the hydrologic year. For example, in the test site where the well P1 has been drilled, the depth at which the contrast between the more and the less fissured bedrock has been detected ( 70 meters below the ground, Petrella et al., 2009b) is close to the maximum depth at which the hydraulic head has been recorded from 2005 on ( 73 meters below the ground). Moreover, taking into consideration that in high flow the hydraulic head at this site rises close to the ground surface, the mixing between waters with different chemical composition occurs within a several tens of metersthick limestone bedrock.

In a wider context, these statements suggest the existence of two different scenarios at least, at catchment scale.

Where the uppermost limestone bedrock is nearly completely involved in head fluctuations during the hydrologic year, the following sequence is expected, from the top to the bottom: (a) epikarst, (b) limestone bedrock with well-developed fissure network and relatively high effective porosity, due to stress release fracturing and mixing of water with different chemical composition, (c) limestone bedrock with poorlydeveloped opening network (box A in Fig. 6). In this scenario, the complete mixing of water is expected to occur within the phreatic zone, as observed in the studied test site.
Conversely, where the hydraulic head fluctuates in the deeper limestone bedrock, a more complex scenario is expected. From the top to the bottom, the sequence is made of (a) epikarst, (b) limestone with well-developed fissure network mainly due to stress release fracturing, (c) limestone with poorly-developed fissure network, (d) limestone with well-developed fissure network and relatively high effective porosity, due to mixing of water with different chemical composition, (e) deeper limestone bedrock with poorly developed fissure network (box B in Fig. 6). In this second scenario, the complete mixing of water might occur within the unsaturated zone.

At catchment scale, mixing processes are further influenced by discontinuous heterogeneities, due to fault zones, where physical characteristics of the carbonate bedrock can be locally influenced also by tectonics, with coexistence (at metric, decametric or hectometric scale) of fault core and damage zone (eg. Mollema \& Antonellini, 1999; Salvini et al., 1999; Billi et al., 2003; Billi, 2005; Agosta \& Aydin, 2006; Billi et al., 2007; Balsamo et al., 2008; Storti \& Balsamo, 2010). Fault cores can include single slip surfaces (Caine et al., 1991), highly indurated, cataclastic zones (Chester \& Logan, 1986), brecciated and geochemically altered zones (Sibson, 1977), or unconsolidated clay-rich gouge zones (Anderson et al., 1983). The damage zone includes fault-

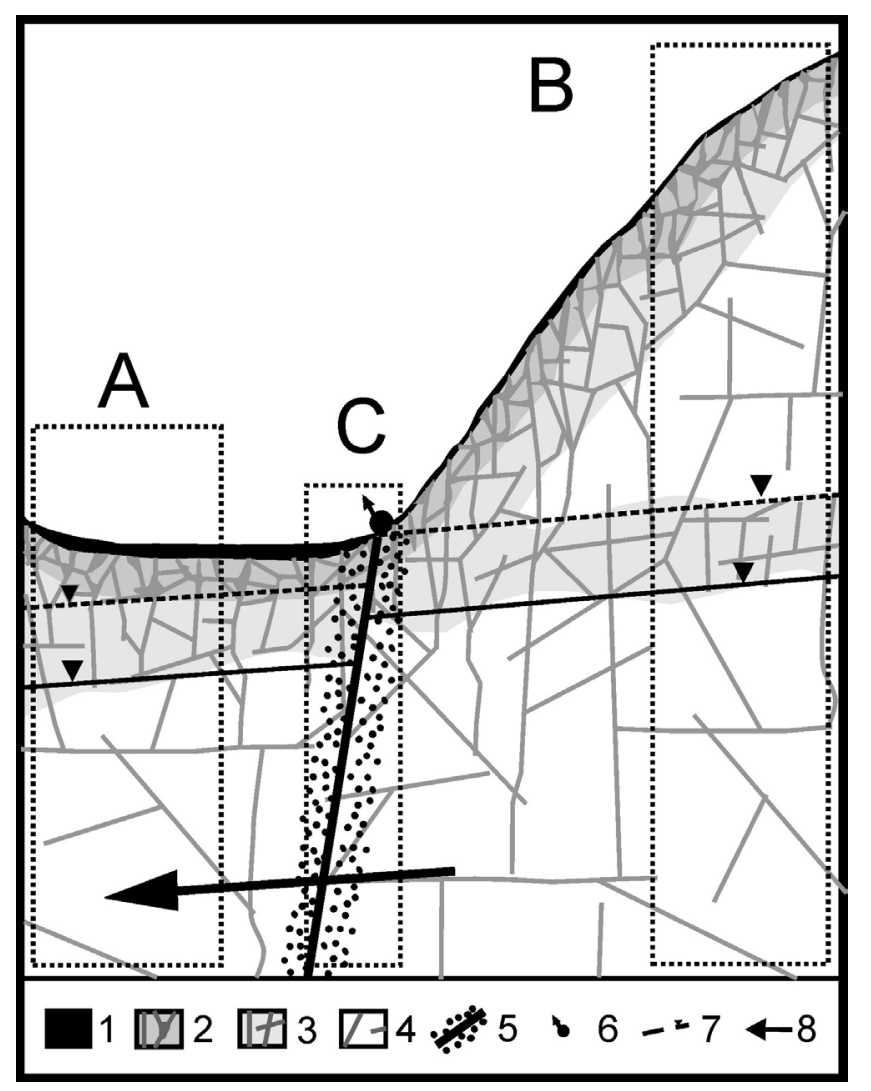

Fig. 6. Conceptual model (not to scale) showing both layered and discontinuous heterogeneities influencing mixing processes within the aquifer system (1 topsoil; 2 epikarst; 3 limestone bedrock with welldeveloped fissure network due to (a) stress release fracturing and/or (b) carbonate dissolution due to mixing between water with different chemical composition; 4 limestone bedrock with poorly-developed fissure network; 5 fault zone; 6 spring; 7 hydraulic head in low- [solid line], and in high-flow period [dashed line]; 8 groundwater flow). 


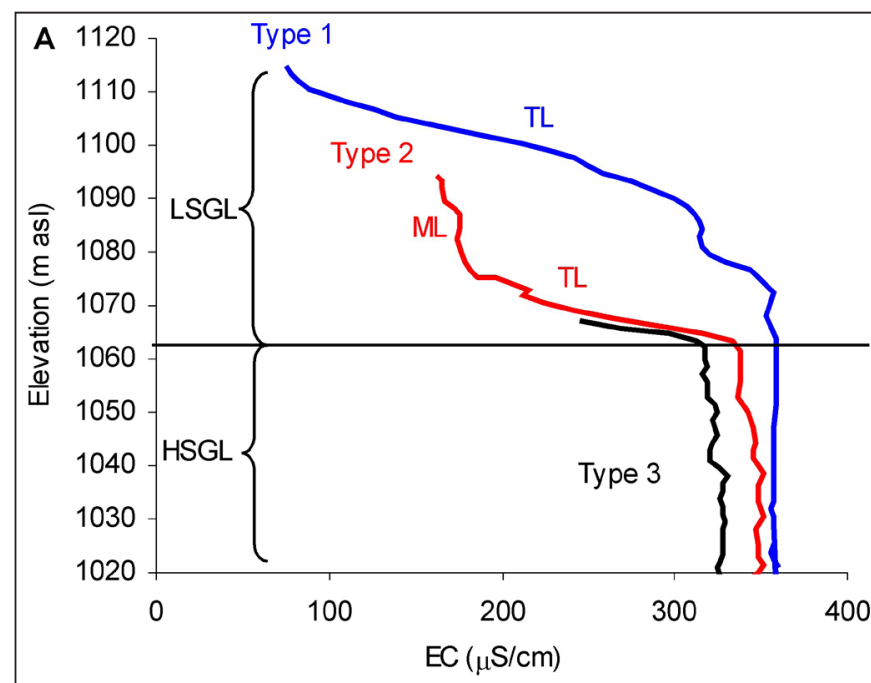

Fig. 7. Non-permanent haloclines observed in $\mathrm{P} 1$, within the protolith. No nearby faults are observed upgradient of P1 (modified from Petrella et al., 2009b).

related subsidiary structures and can enhance fault zone permeability relative to the core and the undeformed protolith (e.g. Chester \& Logan, 1986; Andersson et al., 1991; Goddard \& Evans, 1995). Thus, mixing of water is expected to occur within these zones, due to coexistence of thinner and thicker openings in a complex architecture (box C in Fig. 6). The hypothesis that mixing processes can occur through fault zones is supported by comparison of electrical conductivity (EC) vertical profiles in groundwater within the protolith and close to fault zones, downgradient of the faults. In former studies (Petrella et al., 2009a, 2009b), non-permanent haloclines were observed within the protolith of the studied aquifer system, due to non-complete mixing between fresh-infiltration water and preevent water in the shallower groundwater (in Fig. 7, examples of haloclines observed in the same well P1 used within this study are shown; no nearby faults are observed upgradient of $\mathrm{P} 1$; Fig. 1). On the contrary, a few tens of meters downgradient of a normal fault, the EC vertical profile is homogeneous down to the maximum investigated depth throughout the hydrologic year, despite recharge and layered heterogeneity of the carbonate bedrock (Fig. 8). We interpret this phenomenon as the result of mixing, through the fault zone, between lower and higher salinity groundwater layers flowing upgradient of the fault.

Summarising, mixing processes in the studied aquifer system are influenced by both the layered and the discontinuous heterogeneity. Thus, different scenarios coexist at catchment scale, and this complex setting must be taken into consideration when interpreting chemographs and isotopic signals of perennial, seasonal and temporary spring-waters.
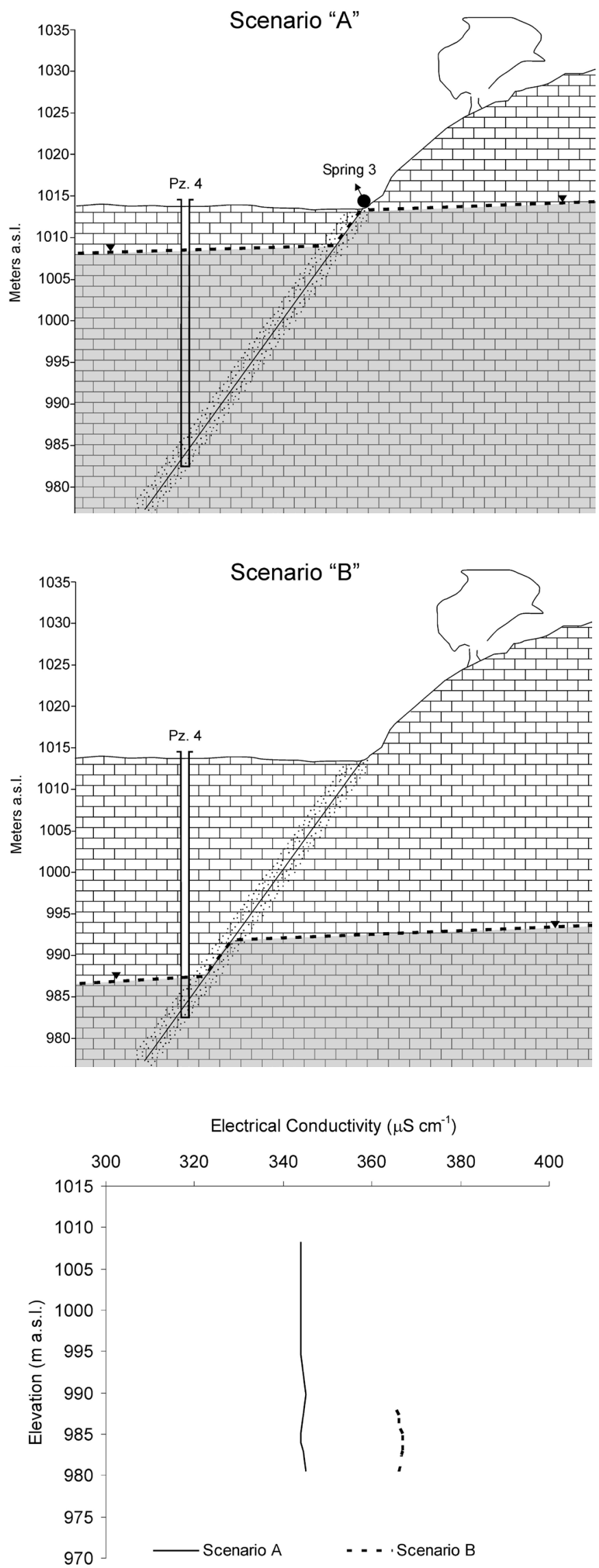

Fig. 8. Homogeneous EC vertical profiles observed in a well located a few tens of meters downgradient of a normal fault, in high (Scenario "A") and in low (Scenario "B") flow periods (modified from Petrella et al., 2008). 


\section{ACKNOWLEDGEMENTS}

This work was supported by grants from European Union (CC-WaterS program) and the Ministero dell'Istruzione, dell'Università e della Ricerca (PRIN2008TL25YL).

\section{REFERENCES}

Agosta F. \& Aydin A., 2006 - Architecture and deformation mechanism of a basin-bounding normal fault in Mesozoic platform carbonates, central Italy. Journal of Structural Geology, 28: 1445-1467. http://dx.doi.org/10.1016/j.jsg.2006.04.006

Anderson L.J., Osborne R.H. \& Palmer D.F., 1983 Cataclasticrocks of the San Gabrielfault. Anexpression of deformation at deeper crustal levels in the San Andreas fault zones. Tectonophysics, 98: 209-251. http://dx.doi.org/10.1016/0040-1951(83)90296-2

Andersson J.E., Ekman L., Nordqvist R. \& Winberg A., 1991 - Hydraulic testing and modeling of a low-angle fracture zone at Finnsjon, Sweden. Journal of Hydrology, 126: 45-77. http://dx.doi.org/10.1016/0022-1694(91)90200-2

Atkinson T.C., 1977 - Diffuse flow and conduit flow in limestone terrain in the Mendip Hills, Somerset (Great Britain). Journal of Hydrology, 35: 93-110. http://dx.doi.org/10.1016/0022-1694(77)90079-8

Baker A., Barnes W.L. \& Smart P.L., 1997 - Variations in the discharge and organic matter of stalagmite drip waters in Lower Cave, Bristol. Hydrological Processes, 11: 1541-1555. http://dx.doi.org/10.1002/(SICI)10991085(199709) 11:11<1541::AID-HYP484>3.0.CO;2-Z

Baker A. \& Brundson C., 2003 - Non-linearities in drip water hydrology: An example from Stump Cross Cavern, Yorkshire. Journal of Hydrology, 277: 151-163. http://dx.doi.org/10.1016/S0022-1694(03)00063-5

Baker A., Genty D. \& Fairchild I.J., 2000 - Hydrological characterisation of stalagmite drip waters at Grotte de Villars, Dordogne, by the analysis of inorganic species and luminescent organic matter. Hydrology and Earth System Sciences, 4: 439-449. http:/ / dx.doi.org/10.5194/hess-4-439-2000

Balsamo F., Storti F., Piovano B., Salvini F., Cifelli F. \& Lima C., 2008-Time dependent structuralarchitecture of subsidiary fracturing and stress pattern in the tip region of an extensional growth fault system, Tarquinia basin, Italy. Tectonophysics, 454: 54-69. http://dx.doi.org/10.1016/j.tecto.2008.04.011

Billi A., 2005 - Attributes and influence on fluid flow of fractures in foreland carbonates of southern Italy. Journal of Structural Geology, 27: 1630-1643. http://dx.doi.org/10.1016/j.jsg.2005.05.001

Billi A., Salvini F. \& Storti F., 2003 - The damage zonefault core transition in carbonate rocks: implications for fault growth, structure and permeability. Journal of Structural Geology, 25: 1779-1794. http://dx.doi.org/10.1016/S0191-8141(03)00037-3 Billi A., Valle A., Brilli M., Faccenna C. \& Finiciello R., 2007 - Fracture-controlled fluid circulation and dissolutional weathering in sinkhole-prone carbonate rocks from central Italy. Journal of Structural Geology, 29: 385-35. http://dx.doi.org/10.1016/j.jsg.2006.09.008

Caine J.S., Coates D.R., Timoffeef N.P. \& Davis W.D., 1991 - Hydrogeology of the Northern Shawangunk Mountains. New York State Geological Survey OpenFile Report 1g806, 72 pp. and maps.
Celico F., Varcamonti M., Guida M. \& Naclerio G., 2004a - Influence of precipitation and soil on transport of fecal enterococci in fractured limestone aquifers. Applied and Environmental Microbiology, 70: 2843 - 2847. http://dx.doi.org/10.1128/AEM.70.5.2843-2847.2004

Celico F., Musilli I. \& Naclerio G., 2004b - The impacts of pasture and manure-spreading on microbial groundwater quality in carbonate aquifers. Environmental Geology, 46: 233 - 236. http://dx.doi.org/10.1007/s00254-004-0987-2

Celico F., Petrella E. \& Celico P., 2006 - Hydrogeological behaviour of some fault zones in a carbonate aquifer of Southern Italy: an experimentally based model. Terra Nova, 18: 308-313. http://dx.doi.org/10.1111/j.1365-3121.2006.00694.x Celle-Jeanton H., Travi Y. \& Blavoux B., 2001 Isotopic typology of the precipitation in the Western Mediterranean region at three different time scales. Geophysical Research Letters, 28: 1215-1218. http://dx.doi.org/10.1029/2000GL012407

Chester F.M. \& Logan J.M., 1986 - Composite planar fabric of gouge from the Punchbowl fault, California. Journal of Structural Geology, 9: 621-634. http://dx.doi.org/10.1016/0191-8141(87)90147-7

Craig H., 1961. Isotopic variations in meteoric waters. Science, 133: 1833-1834.

http://dx.doi.org/10.1126/science.133.3465.1702

Cruz Jr. F.W., Karmann I., Viana Jr. O., Burns S.J., Ferrari J.A., Vuille M., Sial, A.N., Moreira M.Z., 2005 - Stable isotope study of cave percolation waters in subtropical Brazil. Implications for paleoclimate inferences from speleothems. Chemical Geology, 220: 245-262.

http://dx.doi.org/10.1016/j.chemgeo.2005.04.001

De Corso S., Scrocca D. \& Tozzi M., 1998 - Geologia dell'anticlinale del Matese e implicazioni per la tettonica dell'Appennino molisano. Bollettino della Società Geologica Italiana, 117: 419-441.

Ferguson H.F., 1967 - Valley stress release in the Allegheny Plateau. Bulletin of Engineering Geology, 4: 63-71.

Ford D. \& Williams P., 1989 - Karst Geomorphology and Hydrology. Chapman and Hall, London, 601p.

Gabrovšek F. \& Dreybrodt W., 2000 - Role of mixing corrosion in calcite-aggressive $\mathrm{H}_{2} \mathrm{O}-\mathrm{CO}_{2}-\mathrm{CaCO}_{3}$ solutions in the early evolution of karst aquifers in limestone. Water Resources Research, 36: 1179-1188. http://dx.doi.org/10.1029/1999WR900337

Gabrovšek F. \& Dreybrodt W., 2010 - Karstification in unconfined limestone aquifers by mixing of phreatic water with surface water from a local input: a model. Journal of Hydrology, 386: 130-141. http://dx.doi.org/10.1016/j.jhydrol.2010.03.015

Gat J.R. \& Carmi, I., 1970 - Evolution of the isotopic composition of atmospheric waters in the Mediterranean sea area. Journal of Geophysical Research, 75: 3039-3047. http: / / dx.doi.org/10.1029/JC075i015p03039

Genty D. \& Deflandre G., 1998 - Drip flow variations under a stalactite of the Père Noel cave, Belgium. Evidence of seasonal variations and air pressure constraints. Journal of Hydrology, 211: 208-232. http:/ / dx.doi.org/10.1016/S0022-1694(98)00235-2

Goddard J.V. \& Evans J.P., 1995 - Chemical changes and fluid-rock interaction in faults of crystalline thrust sheets, northwestern Wyoming, U.S.A. Journal of Structural Geology, 17: 533-547. http://dx.doi.org/10.1016/0191-8141(94)00068-B

Karmann I., Cruz Jr. F.W., Viana Jr. O. \& Burns S., 2007 - Climate influence on geochemistry parameters of waters from Santana-Pérolas cave system, Brazil. Chemical Geology, 244: 232-247.

http://dx.doi.org/10.1016/j.chemgeo.2007.06.029 
Kaufman A., Bar-Matthews M., Ayalon A. \& Carmi I., 2003 - The vadose flow above Soreq Cave, Israel: A tritium study of the cave waters. Journal of Hydrology, 273: 155-163. http://dx.doi.org/10.1016/S0022-1694(02)00394-3

Lange J., Arbel Y., Grodek T. \& Greenbaum N., 2010 - Water percolation process studies in a Mediterranean karst area. Hydrological Processes, 24: 1866-1879. http://dx.doi.org/10.1002/hyp.7624 Maloszewski P., Stichler W., Zuber A. \& Rank D., 2002 - Identifying the flow systems in a karstic-fissured-porous aquifer, the Schneealpe, Austria, by modelling of environmental ${ }^{18} \mathrm{O}$ and ${ }^{3} \mathrm{H}$ isotopes. Journal of Hydrology, 256: 48-59. http://dx.doi.org/10.1016/S0022-1694(01)00526-1

McDonald J. \& Drysdale R., 2007 - Hydrology of cave drip waters at varying bedrock depths from a karst system in southeastern Australia. Hydrological Processes, 21: 1737-1748. http://dx.doi.org/10.1002/hyp.6356

Mollema P.N. \& Antonellini M., 1999 - Development of strikeslip faults in the dolomites of the Sella Group, Northern Italy. Journal of Structural Geology, 21: 273-292. http://dx.doi.org/10.1016/S0191-8141(98)00121-7 Naclerio G., Petrella E., Nerone V., Allocca V., De Vita P. \& Celico F. 2008 - Influence of topsoil of pyroclastic origin on microbial contamination of groundwater in fractured carbonate aquifers. Hydrogeology Journal, 16: 1057-1064.

http://dx.doi.org/10.1007/s10040-008-0297-y

Naclerio G., Nerone V., Bucci A., Allocca V \& Celico F., 2009 - Role of organic matter and clay fraction on migration of Escherichia coli cells through pyroclastic soils, southern Italy. Colloids and Surfaces B: Biointerfaces, 72: 57-61.

http://dx.doi.org/10.1016/j.colsurfb.2009.03.009

Petrella E., Capuano P. \& Celico F., 2007 - Unusual behaviour of epikarst in the Acqua dei Faggi carbonate aquifer (Southern Italy). Terra Nova, 19: 82-88.

http://dx.doi.org/10.1111/j.1365-3121.2006.00720.x

Petrella E., Falasca A. \& Celico F., 2008 - Naturalgradient tracer experiments in epikarst: A test study in the Acqua dei Faggi experimental site, southern Italy. Geofluids, 8: 159-166.

http://dx.doi.org/10.1111/j.1468-8123.2008.00214.x

Petrella E., Capuano P., Carcione M. \& Celico F., 2009a - A high-altitude temporary spring in a compartmentalized carbonate aquifer: the role of low-permeability faults and karst conduits. Hydrological Processes, 23: 3354-3364.

http://dx.doi.org/10.1002/hyp.7454

Petrella E., Naclerio G., Falasca A., Bucci A., Capuano P., De Felice V. \& Celico F., 2009b - Non-permanent shallow halocline in a fractured carbonate aquifer, southern Italy. Journal of Hydrology, 373: 267-272. http://dx.doi.org/10.1016/j.jhydrol.2009.04.033
Pinder G.F. \& Jones J.F., 1969 - Determination of the groundwater component of peak discharge from the chemistry of total runoff water. Water Resources Research, 5: 438-445.

http://dx.doi.org/10.1029/WR005i002p00438

Romanov D., Gabrovšek F. \& Dreybrodt W., 2003 The impact of hydrochemical boundary conditions on the evolution of limestone karst aquifers. Journal of Hydrology, 276: 240-253.

http://dx.doi.org/10.1016/S0022-1694(03)00058-1

Salvini F., Billi A. \& Wise D.U., 1999 - Strike-slip fault-propagation cleavage in carbonate rocks: the Mattinata Fault Zone, Southern Apennines, Italy. Journal of Structural Geology, 21: 1731-1749. http://dx.doi.org/10.1016/S0191-8141(99)00120-0

Sasowsky I.D. \& White W.B., 1994 - The role of stress release fracturing in the development of cavernous porosity in carbonate aquifers. Water Resources Research, 30: 3523-3530. http://dx.doi.org/10.1029/94WR01727

Schwarz K., Barth J.A.C., Postigo-Rebollo C. \& Grathwohl P., 2009 - Mixing and transport of water in a karst catchment: a case study from precipitation via seepage to the spring. Hydrology and Earth System Sciences, 13: 285-292.

http://dx.doi.org/10.5194/hess-13-285-2009

Sibson R.H., 1977 - Fault rocks and fault mechanisms. Journal of Geological Society of London, 133: 191231. http://dx.doi.org/10.1144/gsjgs.133.3.0191

Sklash M.G. \& Farvolden R.N., 1979 - The role of groundwater in storm runoff. Journal of Hydrology, 43: 4565. http://dx.doi.org/10.1016/0022-1694(79)90164-1

Spötl C., Fairchild I.J. \& Tooth A.F., 2005 - Cave air control on dripwater geochemistry, Obir Caves (Austria): implications for speleothem deposition in dynamically ventilated caves. Geochimica et Cosmochimica Acta, 69: 2451-2468.

http://dx.doi.org/10.1016/j.gca.2004.12.009

Storti F. \& Balsamo F., 2010 - Impact of ephemeral cataclastic fabrics on laser diffraction particle size distribution analysis in loose carbonate fault breccia. Journal of Structural Geology, 32: 507522. http://dx.doi.org/10.1016/j.jsg.2010.02.006

Tooth A.F. \& Fairchild I.J., 2003 - Soil and karst hydrological controls on the geochemical evolution of speleothems-forming drip waters, Crag Cave, southwest Ireland. Journal of Hydrology, 273: 51-68. http:/ /dx.doi.org/10.1016/S0022-1694(02)00349-9

Yonge C.J., Ford D.C., Gray J. \& Schwarcz H.P., 1985 - Stable isotope studies of seepage water. Chemical Geology, 55: 97-105.

http://dx.doi.org/10.1016/0168-9622(85)90030-2

White W.B., 1988 - Geomorphology and Hydrology of Karst Terrains. Oxford University Press: New York, 464 p.

Williams P.W., 1983 - The role of the subcutaneous zone in karst hydrology. Journal of Hydrology, 61: 45-67. http://dx.doi.org/10.1016/0022-1694(83)90234-2 